\title{
TINGKAT PENGETAHUAN DAN SIKAP IBU TENTANG PAP SMEAR SEBAGAI UPAYA DETEKSI DINI KANKER SERVIKS DI DESA TIHINGAN
}

\author{
A.B.S. Satyarsa ${ }^{1}$, L.H. Wirahartato ${ }^{2}$, L.P.D. Virayanti ${ }^{3}$, K.W.M. Kenwa ${ }^{4}$, P.A.T. \\ Adiputra $^{5}$, dan I.N.G. Budiana ${ }^{6}$
}

\begin{abstract}
ABSTRAK
Tujuan: Untuk mengevaluasi hubungan tingkat pengetahuan dan sikap wanita usia produktif terhadap pap smear. Metode: Penelitian yakni pre-eksperimental crossectional study berbasis masyarakat yang telah dilaksanakan pada tanggal 13 Mei - 14 Mei 2017 di Desa Tihingan, Kabupaten Klungkung, Bali. Variabel yang diperiksa menggunakan kuesioner yang tervalidasi sebelumnya. Data yang diperoleh dianalisis menggunakan SPSS. Hasil: Terdapat 60 responden yang terlibat dalam penelitian ini dengan rerata usia 40,65 (SB 13,32) tahun. Lebih dari setengah respoden memiliki pendidikan tinggi dan $65 \%$ mengetahui kanker serviks. Namun, terdapat $76,7 \%$ tahu tentang pap smear. Tingkat pendidikan memiliki hubungan yang signifikan dengan tingkat pengetahuan tentang pap smear dan sikap dalam pelaksanaan pap smear oleh responden $(\mathrm{p}<0,00)$.
\end{abstract}

Kata kunci: Kanker Serviks, Pengetahuan dan Sikap, Pap smear, Bali

\begin{abstract}
Objective: The aim of this study is to evaluate the association between the level of knowledge and the attitude of local-productive age women toward pap smear. Method: A pre-experimental cross-sectional study-based community was conduct on 13th - 14th May 2017 in Tihingan village, Klungkung district, Bali province using validated questionnaire. Analysis of data by using chi-square with confidence level $95 \%$ or $\mathrm{p}$ value $\leq 0,05$ is categorized as significant. Result: 60 respondents were involved in this study with mean age $40.65 \pm 13.32$ years. More than half of respondents were having high school education and $65 \%$ know about cervical cancer. However, $76.6 \%$ were known about pap smear. The level of education was significantly associated with the level of knowledge about pap smear and attitude of pap smear performance by respondents $(\mathrm{p}<0.00)$.
\end{abstract}

Keywords: Cervical Cancer, Knowledge and Attitude, Pap smear, Bali.

\section{PENDAHULUAN}

Kanker serviks merupakan kanker kedua terbanyak di dunia setelah kanker payudata terutama di negara berkembang (Adiputra dkk., 2014). World Health Organization (WHO) tahun 2013 bahwa terdapat sebesar 26 per 100.000 wanita mengalami kanker serviks di Dunia.

Tahun 2012, diperkirakan sekitar 528.000 kasus baru kanker serviks dan 266.000 kematian terjadi. Kematian tersebut sebesar $87 \%$ terjadi di negara-negara berkembang. Kanker serviks masih menjadi masalah kesehatan pada wanita kususnya di Indonesia yang memiliki angka morbiditas dan mortalitas yang tinggi (Putri dkk., 2018).

Pencegahan terhadap kanker serviks saat ini sudah diupayakan oleh pemerintah salah satunya melalui program vaksinasi kanker serviks gratis di desa-desa dan pemberian informasi dari bagian kesehatan disetiap daerah. Selain itu, dilakukan juga upaya deteksi dini melalui test iva dan pap smear yang dapat dilaksanakan 
di puskesmas. Diharapkan dari program ini dapat menurunkan angka morbiditas dan mortalitas terhadap kanker serviks di Indonesia (Vet dkk., 2012).

Dinas Kesehatan Provinsi Bali juga telah melaksanakan program pencegahan dan deteksi dini ini (Martini, 2013). Namun, pada pengamatan peneliti sampai saat ini di Desa Tihingan masih jarang ada penyuluhan mengenai deteksi dini kanker serviks salah satunya adalah pap smear. Jika ada, penyuluhan tersebut tidak diketahui pasti penerima informasi sudah mengalami peningkatan pengetahuan maupun sikapnya terhadap pelaksanaan pap smear (Tilusari, 2014).

Hal tersebut akan mendukung upaya pemerintah menuju Indonesia sehat (Putri dkk., 2018). Pencegahan akan penyakit kanker serviks ini juga akan meningkatkan kualitas hidup wanita lokal usia produktif. Peningkatan pengetahuan dan sikap ini akan meningkatkan pemahaman akan pelaksanaan upaya deteksi dini dan juga pencegahan terjadinya kanker dimasa mendatang (Satyarsa dkk., 2017).

Berdasarkan permasalahan tersebut, peneliti tertarik untuk meneliti bagaimana hubungan tingkat pengetahuan dan sikap dari wanita usia produktif tentang pap smear serta dalam upaya deteksi dini kanker serviks di Desa Tihingan, Kecamatan Banjarangkan, Kabupaten Klungkung, Bali.

\section{METODE PELAKSANAAN}

Penelitian dilaksanakan di Desa Tihingan, Kecamatan Banjarangkan, Kabupaten Klungkung. Berdasarkan tujuan penelitian, penelitian menggunakkan desain cross sectional. Subjek penelitian adalah wanita lokal dengan usia produktif di Desa Tihingan, Kecamatan Banjarangkan, Kabupaten Klungkung, Bali. Sampel dalam penelitian ini adalah wanita produktif yang ada di Desa Tihingan, Kecamatan Banjarangkan, Kabupaten Klungkung yang memenuhi kriteria yang telah ditetapkan oleh peneliti. Pada penelitian ini menggunakan Explore sampling (Sastroasmoro, 2011). Jumlah sampel dalam penelitian ini sebanyak 60 orang.

Instrumen yang digunakan dalam penelitian ini adalah kuisioner yang telah tervalidasi. Kuisioner untuk mengukur pengetahuan dan sikap dari wanita usia produktif tentang pap smear sebagai upaya deteksi dini kanker serviks. Kuisioner yang digunakan pada penelitian ini sudah divalidasi (Martianus dkk., 2018; Yunus, 2018).

Cara pengambilan data dengan angket menggunakan kuisioner. Petugas pengumpulan data adalah peneliti. Data dianalisis dengan deskripsif pada penjabaran kuesioner dan analitik dengan pengukuran uji chisquare. Analisis akan memperjelas hubungan pengetahuan dan sikap wanita usia produktif terhadap pap smear sebagai deteksi dini kanker serviks. Analisa data dilakukan menggunakan program SPSS (Sastroasmoro, 2011).

\section{HASIL DAN PEMBAHASAN}

\subsection{Karakteristik Responden}

Terdapat 60 subjek yang terlibat dalam penelitian ini, dengan rerata usia 40,65 (SB 13,32) tahun. Lebih dari setengah subjek penelitian berpendidikan lulus SMA $(55 \%, n=33)$. Subjek penelitian yang sudah menikah adalah 81,7\% $(\mathrm{n}=49)$, memiliki riwayat keluarga kanker yaitu 30\% $(\mathrm{n}=18)$, dan 55\% $(\mathrm{n}=33)$ sudah pernah melakukan pap smear.

\subsection{Tingkat Pengetahuan mengenai pap smear pada Wanita Usia Produktif}

Tingkat pengetahuan pada wanita usia produktif mengenai pap smear didapatkan hasil sesuai tabel 1 . yakni sebanyak 31 orang $(51,7 \%)$ memiliki pengetahuan yang baik mengenai pap smear dan juga kanker serviks secara umum. Pada Tabel 1 didapatkan bahwa sikap wanita usia produktif dalam melaksanakan pap smear yakni sebanyak 40 orang $(66,7 \%)$ wanita memiliki sikap yang baik dalam melaksanakan pap smear.

Berdasarkan hasil tabulasi silang antara tingkat pengetahuan dengan riwayat pendidikan responden didapatkan bahwa mayoritas status perkawinan, dan riwayat keluarga dengan tingkat pengetahuan didapatkan bahwa pada mayoritas responden dengan pendidikan lulus SMA memiliki pengetahuan yang baik sebanyak $55,6 \%$ mengenai pap smear.

Hasil diperoleh tersebut memiliki hubungan bermakna antara riwayat pendidikan dengan tingkat pengetahuan. Namun, tidak ditemukan hubungan yang bermakna antara tingkat pengetahuan dengan status perkawinan dan riwayat kanker pada keluarga. Berdasarkan hasil tabulasi silang tersebut tidak didapatkan hasil yang memiliki hubungan signifikan antara sikap dengan riwayat pendidikan, status perkawinan dan riwayat kanker pada keluarga.

\section{2 | BULETIN UDAYANA MENGABDI}


Table 1. Tabulasi Silang Tingkat Pengetahuan dan Riwayat Pendidikan, Status Perkawinan dan Riwayat Keluarga

\begin{tabular}{|c|c|c|c|c|c|c|c|c|c|}
\hline & & & & etaht & & & & & \\
\hline & & ang & Sed & & Bail & & & lah & $p$ \\
\hline & $\mathrm{N}$ & $\%$ & $\mathrm{~N}$ & $\%$ & $\mathrm{~N}$ & $\%$ & $\mathrm{~N}$ & $\%$ & \\
\hline Riwayat Pendidi & & & & & & & & & \\
\hline Lulus SMA & 1 & 3,7 & 11 & 40,7 & 15 & 55,6 & 27 & 45 & $0,004 *$ \\
\hline Tidak lulus SMA & 12 & 36,4 & 5 & 15,2 & 16 & 48,5 & 33 & 55 & \\
\hline Status Perkawin & & & & & & & & & \\
\hline Sudah Menikah & 10 & 20,4 & 14 & 28,6 & 25 & 51 & 49 & 81,7 & 0,748 \\
\hline Belum Menikah & 3 & 27,3 & 2 & 18,2 & 6 & 54,5 & 11 & 18,3 & \\
\hline Riwayat Kanker & & & & & & & & & \\
\hline Ada & 4 & 30,8 & 5 & 26,2 & 9 & 52,4 & 18 & 30 & 0,985 \\
\hline Tidak & 9 & 22,2 & 11 & 27,8 & 22 & 50 & 42 & 70 & \\
\hline
\end{tabular}

*bermakna signifikan $(\mathrm{p}<0,05)$

Tabel 2. Tabulasi silang sikap dan riwayat pendidikan, status perkawinan dan Riwayat Keluarga

\begin{tabular}{|c|c|c|c|c|c|c|c|}
\hline & \multicolumn{4}{|c|}{ Sikap } & & & \multirow{3}{*}{$p$} \\
\hline & \multicolumn{2}{|c|}{ Kurang } & \multicolumn{2}{|c|}{ Baik } & \multicolumn{2}{|c|}{ Jumlah } & \\
\hline & $\mathrm{N}$ & $\%$ & $\mathrm{~N}$ & $\%$ & $\mathrm{~N}$ & $\%$ & \\
\hline \multicolumn{8}{|c|}{ Riwayat Pendidikan } \\
\hline SMA & 7 & 25,9 & 20 & 74,1 & 27 & 45 & 0,271 \\
\hline Tidak SMA & 13 & 39,4 & 20 & 60,6 & 33 & 55 & \\
\hline \multicolumn{8}{|c|}{ Status Perkawinan } \\
\hline Sudah Menikah & 17 & 34,7 & 32 & 65,3 & 49 & 81,7 & 0,637 \\
\hline Belum Menikah & 3 & 27,3 & 8 & 72,7 & 11 & 18,3 & \\
\hline \multicolumn{8}{|l|}{ Riwayat Kanker } \\
\hline Ada & 5 & 27,8 & 13 & 72,2 & 18 & 30 & 0,550 \\
\hline Tidak & 15 & 35,7 & 27 & 64,3 & 42 & 70 & \\
\hline
\end{tabular}

Tabel 3. Tabulasi silang tingkat pengetahuan dan sikap wanita usia produktif tentang pap smear

\begin{tabular}{|c|c|c|c|c|c|c|c|c|}
\hline \multirow{3}{*}{$\begin{array}{l}\text { Pengetahuan } \\
\text { tentang pap } \\
\text { smear }\end{array}$} & \multicolumn{4}{|c|}{ Sikap pap smear } & \multicolumn{2}{|c|}{ Jumlah } & \multirow[t]{3}{*}{$X^{2}$} & \multirow[t]{3}{*}{$p$} \\
\hline & \multicolumn{2}{|c|}{ Kurang } & \multicolumn{2}{|c|}{ Baik } & \multirow[b]{2}{*}{$\mathrm{N}$} & \multirow[b]{2}{*}{$\%$} & & \\
\hline & $\mathrm{N}$ & $\%$ & $\mathrm{~N}$ & $\%$ & & & & \\
\hline Baik & 0 & 0 & 31 & 77,5 & 13 & 21,7 & 34,6 & $0,000 *$ \\
\hline Sedang & 9 & 45 & 7 & 17,5 & 16 & 26,7 & & \\
\hline Kurang & 11 & 55 & 2 & 5 & 31 & 51,7 & & \\
\hline Jumlah & 20 & 33,3 & 40 & 66,7 & 60 & 100 & & \\
\hline
\end{tabular}

*bermakna signifikan $(\mathrm{p}<0,05)$

Berdasarkan hasil tabulasi silang pada Tabel 3, didapatkan tingkat pengetahuan memiliki hubungan bermakna dengan sikap responden mengenai pap smear sebagai deteksi dini pada kanker serviks di Desa Tihingan, Klungkung, Bali ( $\mathrm{p}<0,00)$. Mayoritas responden memiliki pengetahuan baik tentang pap smear juga memiliki sikap yang baik dalam melaksanakan pap smear $(77,5 \%)$.

Kanker serviks adalah salah satu kanker terbanyak yang diderita wanita saat ini (Lyimo \& Beran, 2012). Berdasarkan data WHO tahun 2013, menyatakan kanker serviks menduduki nomer 1 sebagai kanker terbanyak pada wanita. Oleh karena hal tersebut, banyak penelitian yang dilakukan baik untuk mengetahui faktor risiko hingga penatalaksanaan terhadap kanker serviks itu sendiri (Herlambang, 2018). Sampai saat ini belum ditemukan penatalaksanaan pasti dari kanker serviks itu sendiri. Namun telah diperoleh upaya pencegahannya melalui pemberian vaksin anti-virus HPV. Namun, mahalnya vaksin ini kurang terjangkau bagi masyarakat secara umum (Syahputra, 2016; Khotimah dkk., 2017). 
Selain itu, pencegahan faktor risiko juga penting dilakukan sejak dini khususnya bagi wanita usia produktif yang telah mempunyai anak. Risiko tinggi terhadap terjadinya kanker serviks dapat dideteksi sedini mungkin dengan pap smear (Putri dkk., 2018). Metode ini telah dilakukan dengan baik hingga dapat dilaksanakan di puskesmas di desa-desa. Namun, rendahnya pengetahuan masyarkat akan pentingnya deteksi dini kanker serviks menyebabkan rendahnya kesadaran untuk melakukan screening pap smear (Yunus, 2018). Padahal dengan melakukan screening pap smear sejak dini diharapkan dapat menangani sedini mungkin kanker serviks sehingga dapat menurunkan angka mortalitas akibat kanker serviks (Tilusari, 2014). Semakin dini seorang wanita terdiagnosis kanker serviks akan menurunkan tingkat mortalitasnya.

Berbagai studi literatur juga menyatakan bahwa kejadian kanker serviks dipengaruhi oleh berbagai faktor (Lyimo \& Beran, 2012; Martini, 2013; Yunus, 2018). Adapun faktor yang mempengaruhi tersebut salah satunya adalah melakukan hubungan seksual tanpa pelindung (kondom) untuk menurunkan infeksi dari Human Papilloma Virus (HPV). Infeksi HPV memiliki peranan besar terjadinya kanker serviks. Pengetahuan dalam mencegah penyebaran infeksi menular tersebut juga penting diketahui. Penelitian ini juga menunjukan tingkat pengetahuan yang baik dari wanita lokal di desa Tihingan. Disamping itu, sikap juga memiliki andil terhadap pengetahuan masyarakat (Putri dkk., 2018).

Pada hasil yang peneliti temukan yakni sekitar 55\% wanita usia produktif di desa Tihingan telah melaksanakan pap smear. Data respoden yang telah menikah sebanyak 81,7\%. Berdasarkan data tersebut diperlukan upaya lebih meningkatkan minat wanita dalam melakukan skrining pap smear. Sesuai dengan hasil penelitian yang telah dilakukan sebelumnya oleh Martini (2013) bahwa pengetahuan dengan sikap wanita usia subur dengan dilakukannya pemeriksaan pap smear di Puskesmas Sukawati II. Ditambahkan juga hasil penelitian dari Tilusari yang memiliki hubungan bermakna antara pengetahuan dan sikap masyarakat tentang deteksi dini pap smear pada kanker serviks.

Pendidikan juga mempengaruhi tingkat pengetahuan seseorang tentang pencegahan kanker serviks. Wanita dengan tingkat pendidikan tinggi lebih mengetahui pentingnya melakukan deteksi dini pap smear. Bahkan hasil yang ditemukan bahwa wanita dengan tingkat pendidikan rendah memiliki risiko tinggi tidak memiliki pengetahuan dan melakukan pap smear (Putri dkk., 2018; Yunus, 2018). Sehubungan dengan penelitian Syahputra (2016) mengenai peranan penyuluhan untuk dapat meningkatkan pengetahun tentang pap smear.

Berdasarkan penelitian Lyimo \& Beran (2012) bahwa pendidikan memiliki peranan penting untuk meningkatkan pengetahuan khususnya untuk menangkap informasi medis dengan hasil yang baik. Dari hasil yang peneliti dapatkan yakni pengetahuan dan sikap responden yang baik sebesar 77,5\% tentang pap smear. Hal tersebut dipengaruhi oleh tingkat pendidikan yang baik. Sesuai dengan hasil yang diperoleh Khotimah (2017) maupun dari hasil penelitian oleh Putri (2018) menunjukan bahwa peranan pengetahuan memiliki hal yang penting untuk sikap yang baik dan benar tentang deteksi dini pap smear pada kanker serviks.

Peranan puskesmas di desa memiliki peranan penting untuk menyampaikan informasi terkait deteksi dini ini dan juga memberikan informasi terbaru seputar kesehatan pada masyarakatnya, khususnya tentang deteksi dini dan upaya dalam mencegah kanker serviks (Herlambang dkk.,, 2018). Penyebaran informasi yang baik pada masyarakat akan diterima dengan baik dan juga akan sangat bermanfaat bagi masyarakat itu sendiri. Terutama masyarakat dengan riwayat pendidikan yang kurang memadai serta diperlukan upaya yang lebih dalam menjelaskan informasi teruma terkait pencegahan dan deteksi dini suatu penyakit (Martianus dkk., 2018).

Penduduk desa memiliki faktor risiko yang tinggi terkena bahaya penyakit kronis seperti kanker serviks. Hal tersebut disebabkan karena pengetahuan akan pencegahan dan sikap masyarakat masih belum ditingkatkan karena beberapa faktor seperti status pendidikan yang memiliki pengaruh yang besar akan kejadian kanker. Ditambah lagi untuk pengetahuan pengobatan juga sering masyarakat cenderung beralih ke alternatif dikarenakan kurangnya pengetahuan mengenai penyakit tersebut.

Informasi deteksi dini kanker serviks dapat dengan IVA test dan pap smear, pemeriksaan ini penting diketahui bagi wanita yang telah melakukan hubungan seksual maupun yang telah memiliki anak.7 Hasil dari pemeriksaan tersebut dapat menjadi acuan untuk dilakukannya upaya proteksi ataupun terapi jikalau ditemukan hasil yang positif. Khususnya pada daerah-daerah desa dengan lokasi di pedalaman serta sedikitnya informasi mengenai hal ini. Oleh karena itu, diperlukan upaya dalam meningkatan pegetahuan yakni dengan melaksanakan penyuluhan rutin khususnya pada daerah pelosok untuk meningkatkan pengetahuan dan sikap masyarakat tentang pap smear. Diharapkan dengan peningkatan pengetahuan dan sikap masyarakat akan menurunkan prevalesi kejadian kanker serviks.

\section{4 | BULETIN UDAYANA MENGABDI}




\section{KESIMPULAN DAN SARAN}

\subsection{Kesimpulan}

Pada wanita usia produktif dengan pendidikan lebih baik memiliki tingkat pengetahuan tentang pap smear lebih baik. Pengetahuan memiliki hubungan yang penting terhadap sikap pada wanita produktif di desa Tihingan dikarenakan semakin baik pengetahuannya maka makin baik pula upaya pencegahan yang dilakukan dalam hal ini adalah pengetahuan pap smear dan pelaksanaan deteksi dini pap smear pada kanker serviks di Desa Tihingan, Klungkung, Bali.

\subsection{Saran}

Diperlukan pemaparan dan penyuluhan tentang deteksi dini kanker serviks dengan tes pap smear kepada masyarakat dalam meningkatkan pemahaman dan sikap yang lebih baik untuk menurunkan tingkat kejadian kanker serviks di kemudian hari.

\section{UCAPAN TERIMA KASIH}

Terima kasih kepada seluruh anggota muda Komunitas Mahasiswa Peduli Kanker (KOMPAK) yang telah membantu pengambilan data penelitian serta peneliti juga mengucapkan terima kasih karena telah memberikan kesempatan pelaksanaan penelitian kepada ketua pelaksana Grebek Desa yakni M. Fakri Barustan. Terima kasih kepada pembimbing KOMPAK yang juga memberikan kesempatan kepada kami melaksanakan penelitian ini. Peneliti juga mengucapkan terima kasih atas partisipasinya kepada seluruh masyarakat di Desa Tihingan, Banjarangkan, Klungkung.

\section{DAFTAR PUSTAKA}

Herlambang, H., Kusdiyah, E. and Iskandar, M.M. (2018). Peningkatan Pengetahuan Wanita tentang Kanker Serviks dan Pemeriksaan Pap Smear Sebagai Skrining Awal. Jurnal Medic (Medical Dedication). 1:2,82-85.

Khotimah, C., Arum, D. N. S., \& Hernayanti, M. R. (2017). Tingkat Pengetahuan dan Pelaksanaan Pap Smear Pada Ibu Pasangan Usia Subur di Dusun Kemasan Desa Karang Tengah Imogiri Bantul Tahun 2015. Jurnal Kesehatan Ibu dan Anak. 11:2, 4954.

Lyimo, F.S. and Beran, T.N. (2012). Demographic, knowledge, attitudinal, and accessibility factors associated with uptake of cervical cancer screening among women in a rural district of Tanzania: three public policy implications. BMC public health. $12: 1,22$.

Martianus, R., Putri, R.C., Satyarsa, A.B.S., Brahmantya, Y.B. and Abdulhadi, A.F., (2018). 257P Correlation between knowledge and attitudes of female high school students regarding cervical cancer in Denpasar, Bali. Annals of Oncology. 29(suppl_9), pp.mdy436-005.

Martini, Ni Ketut. (2013). Hubungan Karakteristik, Pengetahuan dan Sikap Wanita Pasangan Usia Subur Dengan Tindakan Pemeriksaan Pap smear di Puskesmas Sukawati II. Tersedia pada: http://www. pps. unud. ac. id/thesis/pdf th esis/unud-778265413185 -tesis\% 20ni\% 20ketut\% 20martini\% 20mi km\% 20unud\% 20npm\% 201092161018\% 20juli 202013. Diakses tanggal 24 Februari 2019.

Putri, R.C., Satyarsa, A.B.S., Marina Wirahartato, L., Virayanti, L.P.D., Wiswa Mitra Kenwa, K., Adiputra, P.A.T. dkk. (2018). 403P Knowledge and attitudes of productive age women about visual inspection with acetic acid (VIA) test in early screening of 
cervical cancer in Tihingan village, Klungkung, Bali. Annals of Oncology. 29(suppl_9), pp.mdy442-007.

Sastroasmoro, S. and Ismael, S. (2011). Dasar-dasar metodologi penelitian klinis Edisi ke4. Jakarta: Sagung Seto.

Satyarsa, A.B.S., Diah Virayanti, L.P., Arta Suryantari, S.A. and Adiputra, P.A.T., (2017). 571P Knowledge and attitudes of productive age women about "SADARI" (breast self-assessment) in early detection of breast cancer in Tihingan village, Klungkung, Bali. Annals of Oncology. 28(suppl_10), pp.mdx668-007.

Syahputra, E. and Fidiawati, W.A., (2016). Hubungan Pengetahuan dan Sikap terhadap Tindakan Wanita Pekerja Seksual Tidak Langsung Tentang Pap Smear dan Iva sebagai Deteksi Dini Kanker Serviks di Hotspot X Kecamatan Payung Sekaki Pekanbaru. Jurnal Online Mahasiswa (JOM) Bidang Kedokteran. 3:2,1-15.

Tilusari, S.P. and Fidiawati, W.A., (2014). Gambaran pengetahuan dan sikap wanita pekerja seksual tidak langsung di hotspot jalan Tuanku Tambusai kecamatan Sukajadi Pekanbaru terhadap pap smear dan inspeksi visual asetat sebagai deteksi dini kanker serviks. Jurnal Online Mahasiswa (JOM) Bidang Kedokteran. 1:2,1-8.

Tusta-Adiputra, P.A. and Wibawa-Manuaba, I.B.T. (2014). Correlation of parathyroid hormone-1 receptor expression to bone metastasis of breast carcinoma patients. Age. 20:29,1.

Vet, J.N.I., Kooijman, J.L., Henderson, F.C., Aziz, F.M., Purwoto, G., Susanto, dkk. (2012). Single-visit approach of cervical cancer screening: see and treat in Indonesia. British journal of cancer. 107:5,772.

World Health Organization (WHO). (2013). Global Cancer Burden Rises TO 14.1 Million New Cases in 2012: Marked increase in breasts cancers must be addressed. Switzerland: WHO.

Yunus, S. (2018). Hubungan Karakteristik, Pengetahuan dan Sikap Wanita Pasangan Usia Subur dengan Tindakan Pemeriksaan Pap Smear di Rsia Pertiwi Makassar Tahun 2016. Jurnal Ilmiah Kesehatan Diagnosis. 12:4,373-82. 